DOI: https://doi.org/10.33330/jurteksi.v6i2.593

Available online at http://jurnal.stmikroyal.ac.id/index.php/jurteksi

\title{
IMPLEMENTASI MODEL RAPID APPLICATION DEVELOPMENT PADA SISTEM INFORMASI PERSEDIAAN BARANG DENGAN METODE FIFO
}

\author{
Iqbal Kamil Siregar \\ Sistem Komputer, Sekolah Tinggi Manajemen Informatika dan Komputer Royal \\ email: iqbalkamilsiregar@royal.ac.id
}

\begin{abstract}
Supervision of inventory is very urgent to be done by entrepreneurs who aim to support corporate decision making so that the ideal inventory is obtained. By applying the FIFO (First In First Out) method of stock inventory that comes first, it will be sold or utilized first by the company itself. This means that the goods (same form, type, and name) are first purchased, the item will be sold first. This aims to avoid the expired of these items. The target of the results of this study will be to review the extent of existing procedures and can present information as well as to produce an up-to-date information system to achieve work efficiency. With the application of the RAD (Rapid Application Development) model to the computerized inventory system and also which is equipped with the 2010 visual basic programming language and crystal report reports can help in quick decision making. Implementation with the RAD system to realize inventory information systems has been able to produce products with qualified results. The designed application has been able to complete transaction requirements and manage inventory information with the FIFO method.
\end{abstract}

Keywords: FIFO (first out); Inventory; RAD (application Development)

\begin{abstract}
Abstrak: Pengawasan terhadap persediaan barang sangat mendesak untuk dilakukan oleh pengusaha yang bertujuan untuk mendukung pengambilan keputusan perusahaan sehingga didapatkan persediaan yang ideal. Dengan menerapkan metode FIFO (First In First Out) stok persediaan yang datang pertama kali maka akan dijualkan atau dimanfaatkan terlebih dahulu oleh perusahaan itu sendiri. Artinya bahwa barang (bentuk, tipe dan nama yang sama) yang pertama dibeli maka barang tersebut akan pertama dijualkan. Hal ini bertujuan untuk menghindari expired dari barang-barang tersebut. Sasaran dari hasil penelitian ini nantinya untuk meninjau sejauh mana prosedur-prosedur yang ada dan dapat menyajikan informasi sekaligus untuk menghasilkan suatu sistem informasi yang mutakhir sehingga tercapainya efisiensi kerja. Dengan penerapan model RAD (Rapid Application Development) pada sistem persedian barang yang terkomputerisasi dan juga yang dilengkapi dengan bahasa pemrograman visual basic 2010 dan laporan crystal report dapat membantu dalam pengambilan keputusan yang cepat. Implementasi dengan sistem RAD untuk mewujudkan sistem informasi persediaan barang telah mampu menghasilkan produk dengan hasil yang mumpuni. Aplikasi yang dirancang telah dapat melengkapi keperluan transaksi dan mengelola informasi persediaan barang dengan metode FIFO.
\end{abstract}

Kata kunci: FIFO (First In First Out); Persediaan Barang; RAD (Rapid Application Development) 
DOI: https://doi.org/10.33330/jurteksi.v6i2.593

Available online at http://jurnal.stmikroyal.ac.id/index.php/jurteksi

\section{PENDAHULUAN}

Sistem informasi berlandaskan komputer merupakan salah satu pilihan yang tepat untuk mewujudkan peningkatan produktivitas [1]. Sistem informasi komputer saat ini menggambarkan suatu faktor yang mendasar bagi pelengkap yang sangat penting bagi kebutuhan informasi. Berlimpah sektor yang telah menggunakan sistem informasi komputer sebagai tumpuan untuk pekerjaan, namun pemakaian informasi belum maksimal. Implementasi pengendalian persediaan barang amat penting dilakukan bagi bisnis yang bertujuan untuk mendukung pengambilan keputusan formasi agar didapatkan persediaan yang optimal[2]. Dengan menerapkan metode FIFO (First In First Out) berdasarkan stok persediaan yang datang/masuk pertama kali maka akan dijual atau digunakan terlebih dahulu. Hal ini bertujuan untuk menghindari expired dari barang-barang tersebut [3], [4].

Sasaran dari penelitian ini adalah untuk menjajaki sampai mana kebijakan yang ada dan dapat menyediakan informasi sekaligus untuk mengembangkan suatu sistem informasi yang baru untuk tercapainya efisiensi kerja, dan menerapkan metode FIFO untuk pengolahan data persediaaan barang. Sehingga diharapkan nantinya dapat mempermudah Pemilik toko/grosir dalam hal mengontrol barang yang ada maupun yang habis, juga memanfaatkan dan mengikuti trend teknologi untuk mengimplemnetasikan metode FIFO untuk mengontrol barang yang ada, sehingga dapat mengelola persediaan barang dengan baik dan terkontrol[5], [6].

Persediaan barang merupakan aktivitas dalam proses mengelola data transaksi dan bekal dalam gudang, sistem peersediaan barang biasanya terdiri dari sistem penerimaan barang, sistem pembelian barang dan sistem gudang. Dengan adanya sistem inventori diharapkan dapat mempermudah perusahaan dalam melaksanakan proses inventori secara terjadwal, terkontrol, sistematis dan saling terhubung[7].

Menurut laman Wikipedia Rapid application development (RAD) atau Rapid Prototyping adalah model proses pembangunan perangkat lunak yang tergolong dalam teknik incremental (bertingkat). RAD menekankan pada siklus pembangunan pendek, singkat, dan cepat. Waktu yang singkat adalah batasan yang penting untuk model ini. RAD menggunakan metode iteratif (berulang) dalam mengembangkan sistem di mana working model (model bekerja) sistem dikonstruksikan di awal tahap pengembangan dengan tujuan menetapkan kebutuhan (requirement) user dan selanjutnya disingkirkan. Pada saat melakukan proses perencanaan sistem informasi yang lazim, membutuhkan waktu sekurang-kurangnya 180 hari kerja, akan tetapi dengan menerapkan konsep metode RAD, penyelesaian sistem dapat tergarap selama kurun 30-90 hari[8], [9].

Sistem ini dirancang dengan memanfaatkan aplikasi berbasis desktop dimana disana ditemukan beberapa fitur yang dapat membantu sehingga diketahui barang yang lekas kosong dan barang dengan stok banyak[10], maka dibutuhkan metode FIFO untuk menanggulangi kasus ini. Oleh karena itu, dicoba menerapkan model RAD dengan memadukan pada aplikasi persediaan barang dengan menerapkan metode $F I F O$ (First In First Out), sehingga dihasilkan informasi yang efektif dan efisien dalam menunjang kinerja perusahaan. 
DOI: https://doi.org/10.33330/jurteksi.v6i2.593

Available online at http://jurnal.stmikroyal.ac.id/index.php/jurteksi

\section{METODE}

Penelitian ini dilakukan dengan pola penjabaran serta pembuatan aplikasi memanfaatkan model RAD (Rapid Application Development). [11] Model RAD merupakan satu dari banyak solusi yang terpilih dari model System Development life Cycle (SDLC), dalam waktu sekarang ini telah banyak digunakan untuk memberikan solusi ketidak pastian dan persoalan yang berlangsung apabila masih memanfaatkan acuan yang masih bentuk konservatif. Model RAD ini sangat sinkron untuk mewujudkan bentuk software dengan keperluan darurat dan dengan waktu yang tidak lama dalam proses pengerjaannya. Jika keperluan software dimengerti dengan bagus dan cakupan software juga dibatasi dengan seksama sehingga kelompok dapat menyempurnakan perancangan software dengan tempo waktu yang singkat. Dalam model RAD ini akan dibagi menjadi beberapa kelompok dan menjadi beberapa bagian untuk menangani beberapa elemen, tiap-tiap kelompok dapat dilakukan secara searah[12].

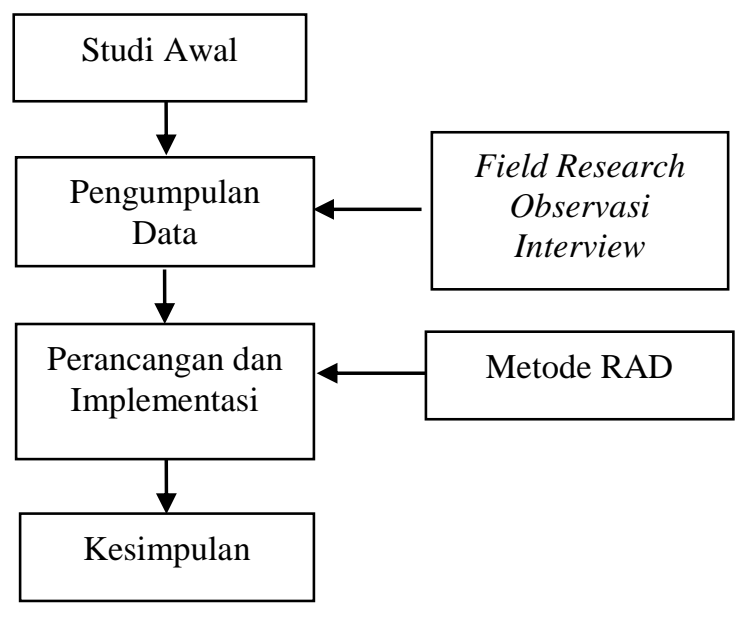

Gambar 1. Urutan Langkah-Langkah Penelitian
Untuk mengatasi permasalahan yang ada, cara pengumpulan data yang dilakukan adalah dengan sistem Penelitian Lapangan (Field Research) dengan melakukan Pengamatan (Observasi) dengan cara melihat serta mempelajari hal-hal yang mempengaruhi proses transaksi dan mengumpulkan data-data yang bersangkutan dengan proses penjualan dan pembelian, selanjutnya dengan melakukan wawancara (interview) untuk mendapatkan data dan informasi yang berhubungan dengan persediaan barang baik dengan mewawancari pemilik toko/ grosir tentang halhal apa saja yang mengakibatkan proses persediaan barang dengan metode FIFO. Urutan tindakan yang dilakukan pada penelitian ini dapat dilihat pada gambar 1.

\section{HASIL DAN PEMBAHASAN}

Berikut ini adalah jenjang proses yang dialului dala pengembangan system dengan Model Rapid Application Development (RAD) Pada Sistem Informasi Persediaan Barang Dengan Metode FIFO:

Tahapan Kerja[2]:

\section{Bussiness Modellling}

Pada tahapan pertama ini akan dilakukan pencarian jalur (aliran) informasi-informasi yang diperlukan yang memuat proses pengolahan data persediaan barang. Masih banyak toko maupun grosir memakai pengolahan informasi data manual yang memperlambat dalam proses pengolahan persediaan barang yang masuk dan barang yang keluar sehingga sulit untuk menentukan barang yang dijual terlebih dahulu. 


\section{Process/Data Modelling}

Pada tahapan ini seluruh data-data dan juga bahan-bahan yang lainnya akan diproses dan diolah. Hasil dari tahapan ini berupa informasi-informasi yang dapat berguna dan juga akan digunakan untuk tahapan selanjutnya. Untuk implementasi metode RAD persedian barang ini diperlihatkan beberapa desain file yang dibutuhkan sebagaimana pada tabel 1 .

Tabel 1. Disain File Pembelian

\begin{tabular}{lcc}
\hline \multicolumn{1}{c}{ Field Name } & Type & Width \\
\hline ID_Transaksi & Varchar & 10 \\
\hline Tanggal & Date & \\
\hline ID_Barang & Varchar & 10 \\
\hline Nama_Barang & Varchar & 20 \\
\hline Satuan & Varchar & 10 \\
\hline Stok_Awal & Int & \\
\hline Jumlah_Masuk & Int & \\
\hline Harga_Masuk & Int & \\
\hline Total_Harga_Masuk & Int & \\
\hline Harga_Keluar & Int & \\
\hline Stok_Akhir & Int &
\end{tabular}

\section{Application Modelling}

Pada tahapan ini, program mulai dibuat. Informasi-informasi yang telah didapatkan dari tahapan-tahapan sebelumnya digunakan oleh programmer selama pembuatan program. Seluruh konsep yang sudah didapatkan juga dijadikan sebagai acuan oleh programmer dalama pembuatan program. Adapun model aplikasi yang digunakan dalam penelitian ini adalah sebagai berikut:

\section{a. Use Case Diagram}

Use case diagram dapat difungsikan selama proses uraian untuk mengambil requirements atau permintaan terhadap sistem dan untuk menanggapi bagaimana sistem tersebut harus berbuat. berikut ini merupakan use case diagram Perancangan persediaan barang dengan Metode FIFO. Berikut ini use case diagram sistem yang diusulkan.

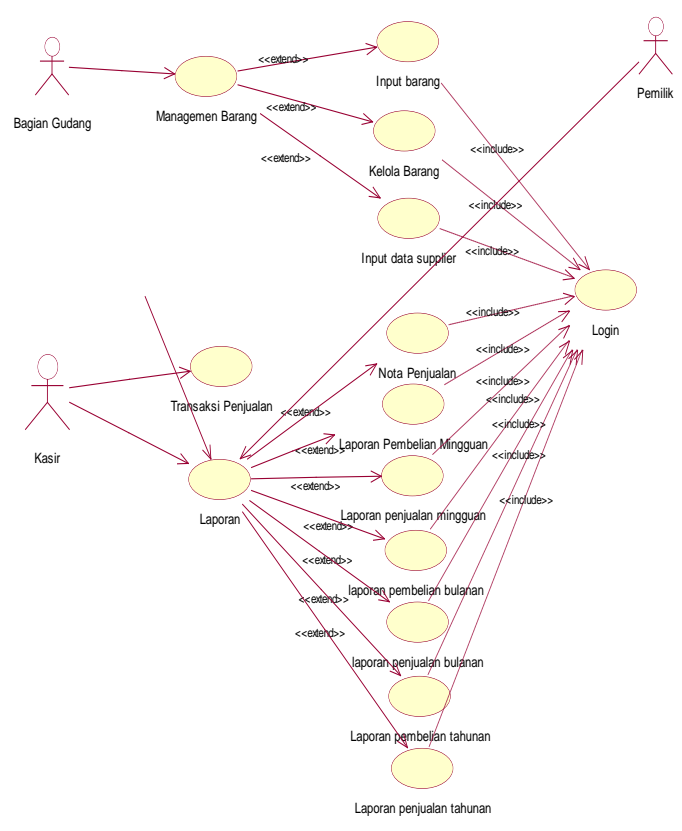

Gambar 3. Use Case Diagram

b. Uraian Prosedur

Analisa sistem pada sistem penjualan dan inventori barang yang di lakukan hanya mencakup Sistem Penjualan Pada Kasir dan Persediaan Barang. Tata laksana dari sistem tersebut adalah dimulai dari pemilihan produk oleh komsumen, komsumen melakukan pembayaran ke kasir, kasir mencatat kode barang dan mencetak struk pembelian, serta memberikannya kepada konsumen.

\section{i. Proses Pembayaran}

Pelanggan datang ke toko/ grosir dan memilih produk yang akan di beli, setelah mendapat produk yang di inginkan pelangan pergi ke kasir untuk melangsungkan 
transaksi pembayaran, setelah konsumen melakukan pembayaran, kasir memberikan struk pembayaran kepada komsumen.

\section{ii. Proses Transaksi Data} barang

Proses ini di lakukan untuk mengontrol barang pada gudang sesuai dengan data masuk. Divisi gudang akan mencocokkan apakah stok barang masih ada atau sudah mengalami penurunan stok. Bagian gudang memberikan laporan barang yang tersedia ke bagian kasir. Kasir memproses dan menginput data pembelian, kasir menyerahkan hasil transaksi persediaan barang ke bagian gudang. Bagian gudang membuat laporan dan memberikannya kepada pimpinan.

iii. Proses Pembuatan Laporan Laporan di buat oleh divisi gudang yaitu laporan transaksi pada gudang dan jumlah barang yang masih tersedia di gudang.

iv. Proses Transaksi Penjualan Proses ini dilakukan untuk transaksi penjualan kepada konsumen dengan metode FIFO, barang yang masuk pertama sekali akan dikeluarkan terlebih dahulu.

\section{c. Implementasi Sistem}

\section{i. Form Transaksi Pembelian}

Form transaksi pembelian ini berfungsi sebagai form yang digunakan untuk proses pembelian berdasarkan tanggal, yang menjadi focus pada bagian penjualan dengan metode FIFO. tampilan form pembelian tertera pada gambar 4.

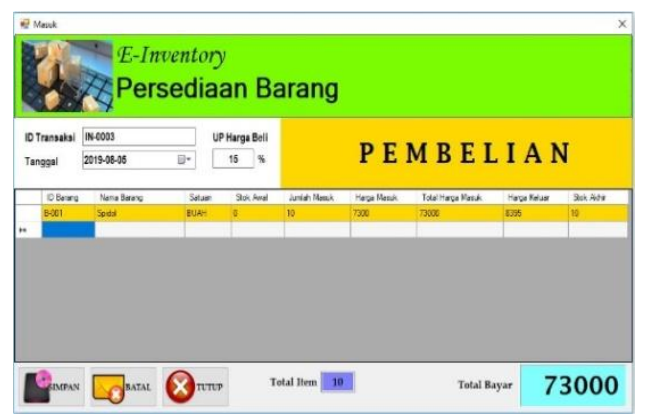

Gambar 4. Tampilan Form Pembelian

ii. Form Transaksi Penjualan Form transaksi pejualan ini berfungsi sebagai form yang digunakan untuk proses transaksi penjualan berdasarkan barang yang beli terlebih dahulu sehinggan barang dijual terlebh dahulu sesuai dengan metode FIFO. Tampilan form penjualan tertera pada gambar 5 .

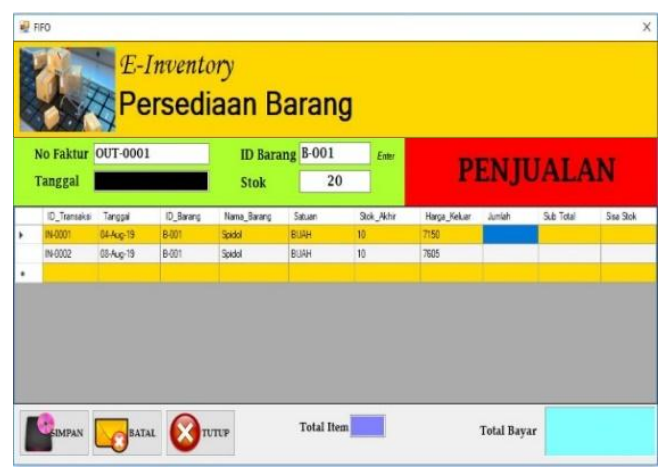

Gambar 5. Tampilan Form Penjualan

\section{SIMPULAN}

Dengan adanya Sistem informasi persediaan barang dengan menggunakan metode FIFO dapat memberikan solusi 
yang tepat dalam pelayanan kepada pelanggan serta memberikan informasi yang dibutuhkan serta menghasilkan laporan yang cepat, tepat dan akurat. Dengan sistem yang terkomputerisasi dan juga yang dilengkapi dengan bahasa pemrograman visual studio 2010 dan laporan crystal report dapat membantu dalam pengambilan keputusan yang cepat.Selanjutnya Pemanfaatan model RAD (Rapid Application Development) untuk mewujudkan sistem informasi persediaan barang sudah dapat memberikan hasil yang optimal. Sistem sudah dapat melengkapi kepentingan transaksi dan mengelola data persediaan barang dengan metode FIFO serta dapat menjawab kebutuhan konsumen untuk memperoleh informasi.

\section{DAFTAR PUSTAKA}

[1] I. K. Siregar et al., "SISTEM INFORMASI STOK OBAT BESERTA ALERT DENGAN VISUAL BASIC 2008," pp. 690693, 2015.

[2] D. Meisak, "Analisis Dan Perancangan Sistem Informasi Persediaan Barang Menggunakan Metode Fifo Pada Pt.Shukaku Jambi," J. MEDIASISFO, 2017.

[3] S. Monalisa et al., "Rancang Bangun Sistem Informasi Inventory Obat Pada Rumah Sakit Jiwa Tampan Berbasis Web," $J$. Sist. Inf., 2018.

[4] D. I. Sari, "Analisis Perhitungan Persediaan Dengan Metode FIFO Dan Average Pada PT. Harapan," Perspektif, 2018.

[5] S. Fauziah and Ratnawati,
"Penerapan Metode FIFO Pada Sistem Informasi Persediaan Barang," J. Tek. Komput., 2018.

[6] P. B. Tarigan, “済無No Title No Title," J. Chem. Inf. Model., vol. 53, no. 9, pp. 1689-1699, 2013.

[7] N. Nurhayati and M. I. Syarif, "SISTEM INFORMASI PENGHITUNG STOK BARANG MENGGUNAKAN METODE FIRST INPUT FIRST OUTPUT (FIFO)dan ECONOMIC ORDER QUANTITY (EOQ)," J. Teknol. Elekterika, 2017.

[8] S. Kosasi, "Penerapan Rapid Application Development Dalam Sistem Perniagaan Elektronik Furniture," Creat. Inf. Technol. J., 2015.

[9] S. Aswati and Y. Siagian, "Model Rapid Application Development Dalam Rancang Bangun Sistem Informasi Pemasaran Rumah (Studi Kasus: Perum Perumnas Cabang Medan," Sesindo, pp. 317-324, 2016.

[10] A. Nasution and I. K. Siregar, "MONITORING STOK BARANG MENGGUNAKAN," pp. 39-44.

[11] A. Febriani and N. Hidayati, "Penerapan Aplikasi Program Penjualan Dan Pembelian Menggunakan Model Rapid Application Development," $J$. Inform., vol. 4, no. 2, pp. 261-271, 2017.

[12] M. P. Putri and H. Effendi, "Implementasi Metode Rapid Application Development Pada Website Service Guide 'Waterfall Tour South Sumatera,"' $J$. SISFOKOM, 2018. 